\title{
Identification of Susceptibility to Malignant Hyperpyrexia
}

\author{
R. F. W. MOULDS, M. A. DENBOROUGH
}

British Medical fournal, 1974, 2, 245-247

\begin{abstract}
Summary
While the serum level of creatine phosphokinase is useful as a screening test for malignant hyperpyrexia it does not provide certain identification of susceptible individuals. A much more accurate prediction may be made by pharmacological testing in vitro of muscle biopsy specimens. Individuals susceptible to malignant hyperpyrexia have muscle with heightened sensitivity to halothane, caffeine, succinylcholine, potassium chloride, and temperature change. Use of this test allows separation of susceptible individuals from those not at risk in families of patients who have experienced malignant hyperpyrexia.
\end{abstract}

\section{Introduction}

The often fatal outcome of malignant hyperpyrexia makes it important to know which patients may develop the syndrome. Previous family studies show that susceptible patients suffer from a myopathy which is usually dominantly inherited and often manifested only by a raised resting serum creatinine phosphokinase (C.P.K.) level (Isaacs and Barlow, 1970; King et al., 1972). Until recently the serum C.P.K. level has been almost the only criterion for identifying patients affected. But C.P.K. levels may be raised in many conditions unassociated with malignant hyperpyrexia (King and Zapf, 1972)—even by strenuous exercise or intramuscular injections-and there is also much variation in the results of C.P.K. estimations. Furthermore, there is no direct evidence that persons with a high serum C.P.K. who are related to patients with malignant hyperpyrexia are themselves susceptible.

Muscle of patients suffering from malignant hyperpyrexia has been shown to react abnormally in vitro when exposed to halothane (Ellis et al., 1971; Moulds and Denborough, 1972) and to caffeine (Kalow et al., 1970), and the use of these abnormal reactions as a more accurate predictive test for malignant hyperpyrexia has been suggested (Ellis et al., 1972; Britt et al., 1973). The present investigation was done to try to learn more about the biochemical basis of the myopathy and to try to find a definitive test for identifying those at risk of developing malignant hyperpyrexia.

\section{Patients and Methods}

In a study of all known cases of malignant hyperpyrexia in Australia and New Zealand King et al. (1972) found evidence of a dominantly inherited myopathy in the form of raised resting serum C.P.K. levels in asymptomatic relatives in nine unrelated families. Six of these families, which included four unrelated survivors of malignant hyperpyrexia, agreed to take part in the investigation. Out of 20 subjects studied 15 (including the four propositi) were thought from their C.P.K. levels to be affected

University of Melbourne Department of Medicine, Royal Melbourne Hospital, Victoria 3050, Australia

R. F. W. MOULDS, B.MED.SCI., M.R.A.C.P., Research Fellow M. A. DENBOROUGH, M.D., F.R.C.P., Reader in Medicine by the myopathy. Each patient was examined for neurological signs of a myopathy and their serum C.P.K. levels were investigated. Motor-point tissue taken from the vastus lateralis muscle was examined by light and electron microscopy, and histochemical and sarcoplasmic reticular studies and in-vitro pharmacological testing (see accompanying paper, Moulds and Denborough, 1974) were carried out. An electrocardiogram, electromyogram, platelet agglutination studies, intravenous glucose tolerance test, and routine serum biochemistry studies were also done in each case.

\section{Results}

The results of the in-vitro pharmacological testing of muscle biopsy specimens have been presented in detail in our accompanying paper (Moulds and Denborough, 1974). From the responses of different preparations from each specimen to exposure to temperature change, halothane, succinylcholine, potassium chloride, and caffeine compared with the responses of muscle known to be normal it was possible to tell whether the specimen was from normal muscle or, because of its increased pharmacological sensitivity, from muscle from a subject susceptible to malignant hyperpyrexia ("malignant hyperpyrexia muscle").

In reporting the results of the present study we first consider the families separately and show the relation of each individual to the propositus and to others in the family (figs. 1,2, and 3), and then report the results in each individual of the in-vitro pharmacological testing, the serum C.P.K. level, and the histochemical findings (see table).

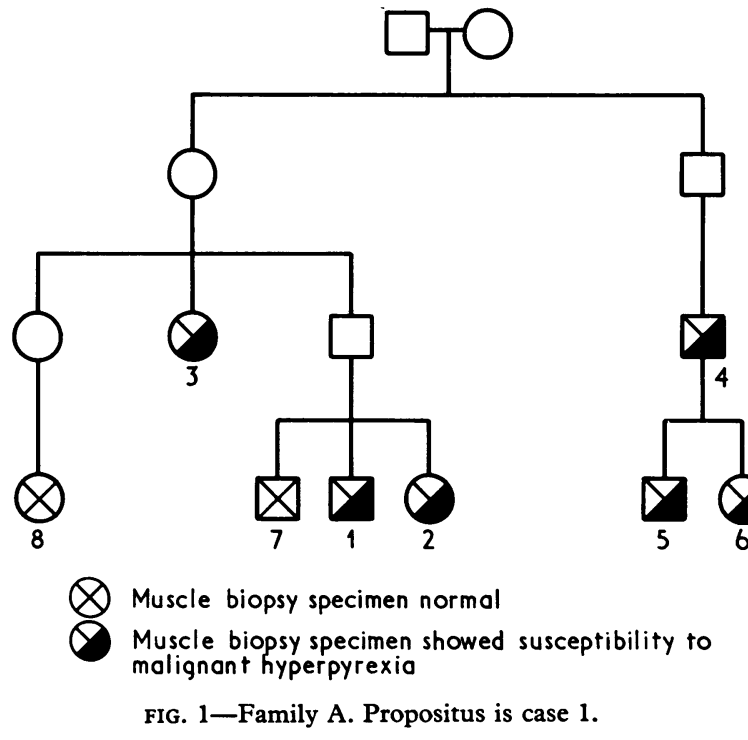

In six members of family A (a family previously described in detail; Denborough et al., 1970; King et al., 1972), including the propositus, the serum C.P.K. levels were distinctly raised and their muscle gave a large contracture on exposure to halothane and also showed greatly increased pharmacological sensitivity. The other two members of the family had normal serum C.P.K. levels and their muscle showed normal pharma- 


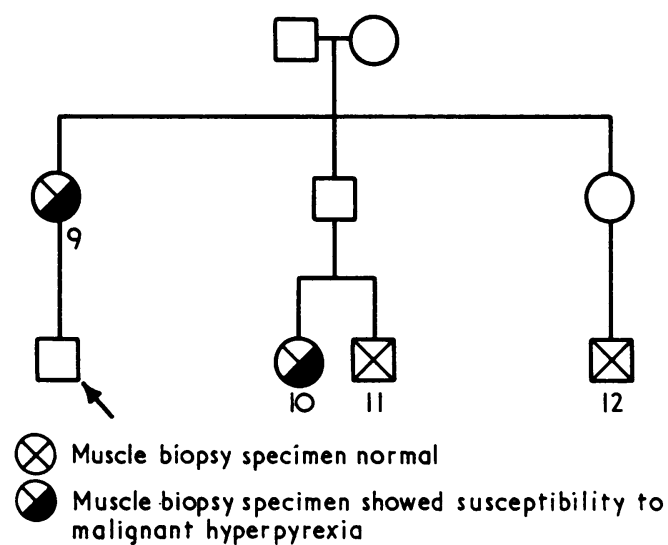

FIG. 2-Family B. Propositus, who died from malignant hyperpyrexia, is arrowed.

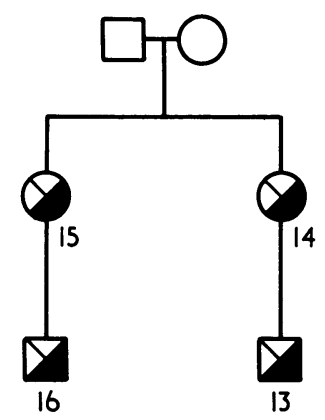

Muscle biopsy specimen showed susceptibility to malignant hyperpyrexio

FIG. 3-Family C. Propositus is case 13.

cological sensitivity, though one specimen (from case 8) gave a very small, slow contracture on exposure to halothane.

Two members of family B had slightly raised serum C.P.K. levels and their muscle gave a contracture on exposure to halothane and showed increased pharmacological sensitivity. The other two members of the family had normal serum C.P.K. levels and normal muscle response.
Muscle from all four members of family $\mathrm{C}$, including the propositus, gave a large contracture on exposure to halothane and showed increased pharmacological sensitivity. The serum C.P.K. levels were variable, however, and in only one member of the family was it more than marginally raised. It should be emphasized that even the propositus's level was only marginally raised.

The only two members of family $\mathrm{D}$ who could be studied were the propositus and his non-identical twin brother. The propositus had a consistently raised serum C.P.K. level and his muscle gave a large contracture on exposure to halothane and showed increased pharmacological sensitivity. His twin brother, however, had a normal C.P.K. level and, though his muscle gave a small contracture on exposure to halothane, it otherwise showed normal pharmacological sensitivity.

Only one member from each of families $\mathrm{E}$ and $\mathrm{F}$ was available for study. Their muscle gave a contracture on exposure to halothane and showed increased pharmacological sensitivity. Each had a raised serum C.P.K. level, though the level in the propositus in one family was only slightly raised.

Electrocardiograms, platelet agglutination studies, and routine serum biochemistry examinations gave normal results in all the subjects. Electromyography showed some of the affected patients to have only mild, non-specific myopathic changes of no diagnostic value. The results of the glucose tolerance tests were abnormal but not diagnostic. They will be presented elsewhere (Denborough et al., 1974). The histochemical and electronmicroscopic studies, which also will be presented in more detail elsewhere, showed the presence of "cores" (Denborough et al., 1973) in all the affected members of family $A$ and in the propositus in family D. Nevertheless, no cores were present in the affected members, including two propositi, of the other four families. Only in family $A$ was there clinical evidence of a myopathy. In families B and $C$ the affected members had well developed musculature and, in particular, very bulky thighs.

\section{Discussion}

Increased in-vitro pharmacological sensitivity with a contracture on exposure to halothane is a reliable means of showing the fundamental abnormality in malignant hyperpyrexia muscle (Moulds and Denborough, 1974). Two points emerge relating to the use of this increased sensitivity as the criterion for identifying patients susceptible to malignant hyperpyrexia.

Details of Findings in the Six Families

\begin{tabular}{|c|c|c|c|c|c|c|c|}
\hline \multirow{2}{*}{ Case No. } & \multirow{2}{*}{ Sex } & \multirow{2}{*}{ Age } & \multirow{2}{*}{$\begin{array}{l}\text { Relation to } \\
\text { Propositus }\end{array}$} & \multirow{2}{*}{$\underset{(\mathrm{mIU} / \mathrm{ml})}{\operatorname{Serum} \text { C.P.K. }}+$} & \multicolumn{2}{|c|}{ In-vitro Pharmacological Testing of Muscle } & \multirow{2}{*}{$\begin{array}{l}\text { Presence of Cores } \\
\text { on Histochemical } \\
\text { Investigation }\end{array}$} \\
\hline & & & & & $\begin{array}{c}\text { Contracture on } \\
\text { Exposure to Halothane }\end{array}$ & Increased Sensitivity & \\
\hline $\begin{array}{l}1 \\
2 \\
3 * \\
4 \\
5 \\
6 \\
7 \\
8\end{array}$ & $\begin{array}{l}\text { M. } \\
\text { F. } \\
\text { F. } \\
\text { M. } \\
\text { F. } \\
\text { M. } \\
\text { F. }\end{array}$ & $\begin{array}{l}35 \\
31 \\
70 \\
54 \\
20 \\
14 \\
36 \\
52\end{array}$ & $\begin{array}{l}\text { Propositus } \\
\text { Sister } \\
\text { Aunt } \\
\text { 2nd Cousin } \\
\text { 3rd Cousin } \\
\text { 3rd Cousin } \\
\text { Brother } \\
\text { Cousin }\end{array}$ & $\begin{array}{c}\text { Family } A \\
971 \\
349 \\
224 \\
495 \\
965 \\
337 \\
47 \\
38\end{array}$ & $\begin{array}{l}+ \\
+ \\
+ \\
+ \\
+ \\
+ \\
+\end{array}$ & $\begin{array}{l}+ \\
+ \\
+ \\
+ \\
+ \\
+ \\
+\end{array}$ & $\begin{array}{l}+ \\
+ \\
+ \\
+ \\
+ \\
+ \\
+ \\
-\end{array}$ \\
\hline $\begin{array}{r}9 \\
10 \\
11 \\
12\end{array}$ & $\begin{array}{l}\text { F. } \\
\text { M. } \\
\text { M. }\end{array}$ & $\begin{array}{l}50 \\
32 \\
25 \\
28\end{array}$ & $\begin{array}{l}\text { Mother } \\
\text { Cousin } \\
\text { Cousin } \\
\text { Cousin }\end{array}$ & $\begin{array}{l}\text { Family } B \\
100 \\
136 \\
19 \\
40\end{array}$ & $\begin{array}{l}+ \\
\pm \\
-\end{array}$ & $\begin{array}{l}+ \\
\pm \\
-\end{array}$ & $\begin{array}{l}\bar{z} \\
\bar{z}\end{array}$ \\
\hline $\begin{array}{l}13 \\
14 \\
15 \\
16\end{array}$ & $\begin{array}{l}\text { M. } \\
\text { F. } \\
\text { M. }\end{array}$ & $\begin{array}{l}26 \\
52 \\
60 \\
33\end{array}$ & $\begin{array}{l}\text { Propositus } \\
\text { Mother } \\
\text { Aunt } \\
\text { Cousin }\end{array}$ & $\begin{array}{l}\text { Family } C \\
75 \\
47 \\
75 \\
112 \\
\text { Family D }\end{array}$ & $\begin{array}{l}+ \\
+ \\
+ \\
+\end{array}$ & $\begin{array}{l}+ \\
+ \\
+ \\
+\end{array}$ & $\bar{z}$ \\
\hline $\begin{array}{l}17 \\
18\end{array}$ & $\begin{array}{l}\text { M. } \\
\text { M. }\end{array}$ & $\begin{array}{l}22 \\
22\end{array}$ & $\begin{array}{l}\text { Propositus } \\
\text { Non-identical Twin }\end{array}$ & $\begin{array}{l}\text { Family } D \\
741 \\
29\end{array}$ & + & \pm & \pm \\
\hline 19 & M. & 18 & Propositus & 110 & + & + & - \\
\hline 20 & M. & 26 & & $\underset{163}{\text { Family } F}$ & + & + & - \\
\hline
\end{tabular}


Firstly, raised serum C.P.K. levels are usually accurate in identifying people affected by the myopathy. The levels may be only mildly raised, however, as exemplified by two of the propositi in this study, and also their predictive value seems to be much less in some families-for example, family $\mathrm{C}$-than in others-for example, family A. Secondly, increased sensitivity to all the pharmacological agents used and not only to halothane must be shown in order to be certain that a patient is affected by the myopathy, because a small contracture sometimes occurs in normal muscle when exposed to halothane though not to the other pharmacological agents. This is best exemplified by family $D$, where the muscle from the non-identical twin brother of the propositus gave a small contracture on exposure to halothane but did not show increased sensitivity to any other pharmacological agent and was therefore not considered to be malignant hyperpyrexia muscle.

This study therefore confirms that serum C.P.K. levels are usually reliable in screening relatives of patients who have suffered from malignant hyperpyrexia for the presence of the predisposing myopathy. But among people who may have raised C.P.K. levels for other reasons or in families where the rise in C.P.K. levels is equivocal affected individuals must be identified by testing their skeletal muscle for increased in-vitro pharmacological sensitivity.
R. F. W. Moulds is a postgraduate research scholar of the National Health and Medical Research Council. We are grateful to the Victor Hurley Research Fund of the Royal Melbourne Hospital for support. We are also indebted to Dr. R. McD. Anderson and Miss X. Dennett for the histological results, to $\mathrm{Mr}$. D. Wallace, Mr. G. Richardson, and Dr. R. Hjorth for the motorpoint biopsies, and to Dr. C. W. Baird for the serum biochemistry.

\section{References}

Britt, B. A., Kalow, W., Gordon, A., Humphrey, J. G., and Rewcastle, N. B. (1973). Canadian Anaesthetists' Society fournal, 20, 431

Denborough, M. A., Dennett, X., and Anderson, R. MCD. (1973). British Medical fournal, $1,272$.

Denborough, M. A., Ebeling, P., King, J. O., and Zapf, P. (1970). Lancet, 1, 1138.

Denborough, M. A., et al. (1974). Unpublished.

Ellis, F. R., Harriman, D. G. F., Keaney, N. P., Kyei-Mensah, K., and Tyrell,' J. H. (1971). British fournal of Anaesthesia, 43, 721.

Ellis, F. R., et al. (1972). British Medical fournal, 3, 559.

Isaacs, H., and Barlow, M. B. (1970). British Medical fournal, 1, 275.

Kalow, W., Britt, B. A., Terreau, M. E., and Haist, C. (1970). Lancet, 2, 895.

King, J. O., Denborough, M. A., and Zapf, P. (1972). Lancet, 1, 365.

King J. O, and Zapf, P. (1972). Medical fournal of Australia, 1, 699.

Moulds, R. F. W., and Denborough, M. A. (1974). British Medical fournal,

2, 241. F. W., and Denborough, M. A. (1972). British Medical fournal,
Moulds, R. F. 4,526 .

\title{
Diagnosis and Treatment of Essential Fatty Acid Deficiency in Man
}

\author{
M. PRESS, H. KIKUCHI, T. SHIMOYAMA， G. R. THOMPSON
}

British Medical fournal, 1974, 2, 247-250

\section{Summary}

Essential fatty acid deficiency was found on four occasions in three adult patients with malabsorption after intestinal resection. Diagnosis was primarily based on the gas chromatographic finding of the abnormal fatty acid $5,8,11-(\omega 9)$ eicosatrienoic acid in plasma lecithin. None of the patients had received parenteral nutrition with a fat-free source of calories but all had been on a reduced intake of dietary fat at some stage. Treatment with intravenous Intralipid rapidly reversed the abnormal plasma fatty acid pattern and also cleared the rash in the patient wih he most severe deficiency.

\section{Introduction}

The two major essential fatty acids (E.F.A.) found in man are linoleic acid and arachidonic acid. Both are important constituents of cell membranes. Arachidonic acid is synthesized from linoleic acid in the liver but man, in common with all other vertebrates lacks the ability to synthesize linoleic acid de novo. Yeasts and plants, however, have enzymes capable

\footnotetext{
Department of Medicine, Royal Postgraduate Medical School, Hammersmith Hospital, London W12 OHS

M. PRESS, M.Sc., M.R.C.P., Registrar (Present address: M.R.C. Lipid Metabolism Unit, Hammersmith Hospital)

H. KIKUCHI, M.D., Research Assistant (Present address: Senior Lecture in Internal Medicine, Hirosaki University School of Medicine, Hirosaki, Aomori, Japan)

T. SHIMOYAMA, M.D., Research Assistant (Present address: Professor of Internal Medicine, Hyogo College of Medicine, Nishinomiya, Hyogo,

G. R. THOMPSON, M.D., F.R.C.P., Senior Lecturer
}

of inserting the double bond between the sixth and seventh carbon atoms of a fatty acid chain (counting from the methyl end) which is the characteristic feature of both these essential fatty acids. Some of the commoner fatty acids found in man and the nomenclature used to describe them are shown in table I. All belong to the $\omega 6$ series. Thus Conversion of linoleic acid $(18: 2 \omega 6)$ to arachidonic acid $(20: 4 \omega 6)$ takes place via the formation of $8,11,14$-eicosatrienoic acid $(20: 3 \omega 6)$, whereas in essential fatty acid deficiency this process ceases and instead oleic acid $(18: 1 \omega 9)$ is converted to $5,8,11$ eicosatrenoic acid $(20: 3 \omega 9)$. The presence of significant amounts of the latter in plasma or tissue phospholipids is regarded as the biochemical hallmark of E.F.A. deficiency.

TABLE I-Major Fatty Acids Found in Man (after Coniglio, 1972)

\begin{tabular}{|c|c|c|c|c|c|}
\hline \multicolumn{5}{|l|}{ Common Name } & \multirow{2}{*}{$\begin{array}{l}\text { Abbreviated Formula } \\
\ldots \quad 16: 0\end{array}$} \\
\hline Palmitic acid & & $\cdots$ & & & \\
\hline Stearic acid & . & .. & - & . & . 18:0 \\
\hline Oleic acid $\ddot{3}$ id & . & . & . & $\cdots$ & $\begin{array}{ll}18: 1 \omega 9 \\
20: 3 \omega 9\end{array}$ \\
\hline $5,8,11$-eicosatrienoic acid $\dagger$ & $\ddot{0}$ & 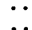 & $\because$ & $\because$ & 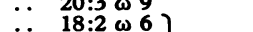 \\
\hline $\begin{array}{l}\text { Linoleic acid } \\
8,11,14-\text { eicosatrienoic acid } \dagger\end{array}$ & $\because$ & $\because$ & $\therefore$ & $\because$ & $20: 3 \omega 6$ \\
\hline Arachidonic acid & .. & .. & .. & .. & .. 20:4 $\omega 6$ \\
\hline
\end{tabular}

* The abbreviated formula indicates the number of carbon atoms and the number of double bonds. The position of the double bond nearest to the methyl terminus, counting from same, is indicated by the symbol $\omega$.

This chemical terminology indicates the number of carbon atoms and the number of double bonds and their location, counting from the carboxyl terminus of the fatty acid.

Absence of E.F.A. from the diet has long been known to give rise to a specific deficiency syndrome in young animals, who fail to grow normally, develop a scaly dermatitis, and have widespread metabolic disturbances (Holman, 1971). A similar syndrome has been described in human infants fed milk formulae containing only saturated fat (Hansen et al., 